\title{
Application of Green Economy in Malini Agro Park
}

\author{
I Wayan Suartana ${ }^{1}$, I Ketut Suryanawa ${ }^{2}$ \\ Department of Accounting \\ Faculty of Economics and Business, Udayana University \\ Jimbaran \\ suark15@yahoo.com \\ Department of Accounting \\ Faculty of Economics and Business, Udayana University \\ Jimbaran
}

\begin{abstract}
Development that exploits natural resources is an easy story to hear. The exploitation-based development model that is maintained will only result in marginalization. A green economy as a means of achieving sustainable development is designed to protect and increase the value of the natural resource base, increase resource efficiency, promote sustainable or environmentally friendly patterns of production and consumption, and encourage the world towards low carbon development. Green economy policies and measures should be designed to improve the integration between economic development and its sustainable aspects. A development that combines economic, social and environmental interests to meet the needs of the current generation without sacrificing the interests of future generations. For this reason, Malini Agro Park, which is located in the arid area of Pecatu, implements an integrated hydroponic system to support sustainable development. The specific objective of this research is to examine in depth the implementation of green accounting at Malini Agro Park.
\end{abstract}

Index Terms - green economy, triple bottom line accounting

\section{INTRODUCTION}

Development that exploits natural resources is an easy story to hear. This trend is even more serious if there are no massive and systematic prevention efforts. Many interests are involved, so mitigation efforts require courage. Maintaining the exploitation-based development model will only result in marginalization [1].

Exploitation of nature to pursue maximum profits for the sake of local revenue (PAD), for example, makes business a paradox with the environment. Public access and public space can be disrupted due to the ambition to pursue asset growth and distribution of wealth in the name of dividends. The social fund tool as a company social concern for the environment called CSR (corporate social responsibility) has started to resonate but it is feared that it is only limited to image management. Empowerment loses touch. It seems that there is no other choice to secure future children and grandchildren other than a consistent attitude towards a green economy [2].

Green economy as a means of achieving sustainable development is designed to protect and increase the value of the natural resource base, increase resource efficiency, 
promote sustainable or environmentally friendly production and consumption patterns, and encourage the world towards low-carbon development [3]. Green economy policies and measures should be designed to improve the integration between economic development and its sustainable aspects. A development that combines economic, social and environmental interests to meet the needs of the current generation without sacrificing the interests of future generations. If we are selfish only thinking about the needs of the present, then future generations will scream for what we are doing now.

The role of regional heads in implementing the green economy is very important in the current era of regional autonomy. Vision, competence, and character of local leaders will greatly determine sustainable development through the vision of a green economy that they carry. This principle will have no meaning if it is limited to rhetoric or is only limited to concepts, discourses, paper tigers dancing without action.

Technically, there may be several problems experienced by local governments in managing this green economy issue. The first problem is the misconception that green economy is synonymous with certain SKPD (Regional Work Units). For example, the Licensing Office, BAPPEDA or technical agencies that take care of reforestation only. Even though the green economy is a problem as a whole SKPD and a comprehensive development problem. The second is that when local governments implement a green economy it may not pay attention to special needs, focus on important situations and conditions and the absence of a set of indicators measuring progress in the implementation of the green economy [4].

Many companies have adopted the concept of maximizing profit (one of the concepts adopted by capitalists) but at the same time they have violated consensus and the principles of profit maximization themselves. The principles that were violated included, among others, the rules of economic costs, accounting costs and opportunity costs. The implications of violating these principles include neglect of environmental management and low levels of environmental performance and low interest in the company for environmental conservation. Opportunity cost violations, for example, have had a significant impact on the sustainability of the global environment. For Indonesia, especially Bali, environmental problems are an important factor that must be considered immediately considering the impact of poor environmental management is increasingly real nowadays. This symptom can be seen from various disasters that have occurred recently, such as landslides, floods and so on. This fact is an implication, both directly and indirectly, of the lack of encouragement and proactive actions for environmental management from various industrial sectors in Indonesia. The specific objective of this research is to examine in depth the implementation of green accounting at Malini
Agro Park.

\section{RESEARCH METHODS}

The study used a combination method of survey and case studies which produced descriptive data, namely written and oral data from interviewed sources and analyzed company documents. The approach used to obtain data in this study is characterized by non-participation observation, which means that the researcher is not involved in the activities of the resource person being observed and is only an independent observer. The researcher notes, analyzes, and then can make conclusions about the implementation of environmental accounting and CSR at Malini Agro Park that has been done.

The research will be conducted at Malini Agro Park in Badung Regency, Bali Province. Malini Agro Park is a business engaged in integrated hydroponics. The research is descriptive qualitative by describing the elements of green economy accounting and the Triple Bottom Line (CSR) of Malini Agro Park.

\section{RESULT AND ANALISYS}

In order to obtain research data, researchers have conducted in-depth interviews with resource persons, namely Wayan Tana, the founder of Malini Agro Park as well as the President Director of PT. Malini Dwipa Nusantara. Interviews and observations were carried out on Friday, October 6, 2017, at Malini Agro Park, Jalan Batu Kandik No. 3 Pecatu Village, South Kuta District, Badung Regency, Bali Province. The interviews conducted included company profiles, company operational activities related to the green economy, the implementation of Tri Hita Karana in company activities, and the implementation of corporate social responsibility towards the environment and society.

\section{A. Profile of Malini Agro Park}

Malini Agro Park is a business engaged in agriculturebased tourism services located in Pecatu Village, South Kuta District, Badung Regency, Bali Province. Malini Agro Park was founded in 2016, under the legal umbrella of a Limited Liability Company (PT) named PT. Malini Dwipa Nusantara. Founder and President Director of PT. Malini Dwipa Nusantara is Wayan Tana. Malini was based on the initiator's desire to return the lost farmers back to being farmers. Since 1970, the barren and arid land of Pecatu Village has caused farmers to fail to support their livelihoods, so that great farmers choose to join the government program, which is to transmigrate outside Bali (such as Kalimantan and Sulawesi). Meanwhile, the remaining farmers choose to change professions, such as becoming tour guides, hotel employees, restaurant employees, and so on. Malini will have its grand opening in January 2018, but since it was founded in 2016 Malini has carried out many activities so that it has been recognized by the public.

Malini Agro Park has an integrated agricultural system 
with hydroponic technology, a culinary center that prioritizes agricultural and plantation products, a recreational park, and an agricultural education center. In a planned, integrated and technological synergy, Malini Agro Park came up with an idea to turn the barren Pecatu Village into a farm using hydroponic and aeroponic garden methods. Hydroponics is the cultivation of planting using water without using soil by emphasizing meeting the nutritional needs of plants. The water requirement in hydroponics is less than the water requirement for cultivation with soil. Hydroponics uses water more efficiently, so it is suitable to be applied in areas that have a limited water supply. Aeroponics is one type of hydroponics, because water containing a nutrient solution is sprayed in the form of mist until it hits the roots of plants. One of the key advantages of aeroponics is the oxygenation of each fine mist of nutrient solution so that root respiration is smooth and produces a lot of energy.

Malini empowers farmers with guidance to do $3 \mathrm{M}$. The first is Management (management), which is thinking about what farmers need, such as seeds, nutrients, fertilizers, providing polybags, etc., so that farmers decide to plant what is needed by the market (market orientation). Second, maintenance (maintenance), namely there are experts who provide "care" to farmers in the form of education. Education emphasizes the important thing for farmers, namely that what is planted must grow, what grows must flower, what flowers must bear fruit, and what bears fruit must be harvested. The third is Marketing (marketing), which is conducting modeling activities, making market segmentation, such as how many kilograms for Malini, for supermarkets, and for clients with a healthy lifestyle. In essence, marketing is trying to figure out how to make what is planted will be distributed and sold. The three points are expected to solve the problems of farmers at this time, so that farmers are not marginalized and only depend on third parties.

\section{B. Green Economy at Malini Agro Park}

A green economy as a means of achieving sustainable development, is designed to protect and increase the value of the natural resource base, increase resource efficiency, promote sustainable or environmentally friendly patterns of production and consumption, and push the world towards low carbon development. The flagship programs carried out by Malini Agro Park focus on agriculture, which is the main natural resource for the fulfillment of community food, as well as a source of livelihood for farmers. There are five excellent programs offered by Malini Agro Park, namely:

\section{Pecatu Farmers Empowerment Program}

Through the Malini Indonesia Foundation, the Pecatu Farmers Empowerment Program is a program to develop and increase the capacity of farmers in the Pecatu area to become smart farmers who understand modern agricultural technology and are responsive to market conditions. Overall, this program includes:
- Provision of superior seeds,

- Planting techniques with the principles of sustainable agriculture,

- Technical assistance in the field,

- Certain market guarantees for the harvest.

2. Organic Mustard Juice Drinking Movement Program

Malini also often participated in exhibition activities held by the Bali provincial government. One of them is participating in the Agricultural Culture Festival in Plaga Village and the Bali Province Agribusiness Festival. The Organic Sawi Juice Drinking Movement is a form of planting a healthy lifestyle for the community from an early age which aims to create high quality public health and become a strong nation.

3. Malini Learning Farm Program

As an initial stage, this program is held almost every Friday, where Malini invites elementary school children, especially in Badung District to learn farming and gardening, to Malini, free of charge. This educational facility aims to introduce the world of agriculture from an early age so that there will be awareness and knowledge of the country's potential as an agricultural country rich in agricultural products.

4. Malini Ambassador Program

Duta Malini is a person or group of people who play an active and real role in the concept of Malini agriculture and its derivatives in the form of cooperation, both business and socially. They include social media actors, tour guides, travel agents, Malini farmers, vegetable sellers, and others. People who contribute to agriculture and are good farmers are called Patriot Malini. Duta Malini needs a good personality who is needed to socialize with the wider community.

5. Malini Agropark Tourism Program

In this program, farmers are the main subject of agrotourism activities. In agro tourism, there are various types of activities, ranging from farming, enjoying services such as bar facilities, restaurants, afternoon tea, then yoga, meditation, learning farms, and cliff adventure. In this agro tourism, it can be said that farmers do their business activities.

In addition to these programs, the results of the interviews provided exposure to several aspects of Triple Bottom Line Accounting and Tri Hita Karana which are reflected in the company's activities.

1. Environmental Aspects

Malini has a Zero KM Organic Farm concept. Zero KM does not produce pollution, even from the highway, Malini is approximately 800 meters away so it does not cause major pollution. This means that all agricultural and plantation products in Malini are pure organic and pollution free. There are recycling activities, namely recycling toilets, separating urine and feces, and recycling manure from cattle. The results will be processed into fertilizers that are used to fertilize plants. 


\section{Energy Aspects}

Malini has not used solar energy, for now she uses the services of PDAM and PLN.

3. Occupational Health and Safety Aspects

There are SOPs that must be used, especially in work equipment, use of shoes and helmets. In the kitchen, Malini follows a certification program to show whether a restaurant in Malini is a healthy restaurant or not, in terms of cleanliness and sanitation. The results of the certification are expected to be obtained in March 2018.

In terms of workforce health services, Malini uses a government program, namely BPJS. In addition, Malini invites tourists and employees to lead healthy lives, through the concept of "farm into the table, we cook what we grow", which means cooking what has been planted.

Currently there are 30 workers, of whom there are 9 farmers, which is planned to be 90 people later when Malini is launched. Of the existing employees, around $30 \%$ are women, then depending on the applicants who will come until Malini is officially opened. For now there are no workers with disabilities, but Malini plans to accept job applicants with disabilities.

Manpower training is also carried out by Malini for its employees, both for farmers and other employees. Malini has never provided financial assistance to workers for formal education, but will provide training if needed for both farmers and other employees. For workers who will later retire, Malini has a policy to provide severance pay. Since 2016, financial reports have been made. Share ownership is regulated in the company establishment deed. Payroll for workers is based on salary, and there are also rewards for workers who perform well.

\section{Product Aspects}

There are various products contained within Malini, such as learning farms, cliff adventure, outbound, and others. Outside Malini, Malini Healthy Rice is produced, which is planned to start running in January 2018 and will be certified organic.

There is a lot of expenditure for research and product development, in which Malini collaborates with the Gadjah Mada University (UGM). Each product development is asked for a study first, for example examining papasan leaves which are abundant in Pecatu village, whether it is healthy for consumption or not. Malini Agro Park applies the results of studies that have been conducted by agricultural experts at UGM. In addition, almost all programs run by Malini are based on existing literatures. Current research costs have not been disclosed in the financial statements, however, Malini received input to consider disclosing research costs in the financial statements.

Efforts to improve hygiene and health in the processing and preparation of products are always carried out, such as inspection of kitchen and garden sanitation, because health and hygiene are the main goals in healthy tourism offered by Malini Agro Park.

5. Aspects of Community Engagement

In the aspect of community involvement, Malini Agro Park contributes in the form of empowering Pecatu farmers to support community activities and try to improve the economy of the Pecatu village community. The Malini party also accepts part-time workers from students and students. At present Malini has never been a sponsor of a public health project, but plans to do so at a later date.

6. Parahyangan Aspects

There is a holy place or place of worship at Malini Agro Park, namely Padma Sari, Penunggun Karang, besides that the Malini area itself is a holy place, because it is located in the Pura Luhur Uluwatu area. In Malini itself, there are many Hindu philosophies that are used as decoration. One of them is the name Malini itself, which comes from Sanskrit, which means a flower that doesn't stop giving off its fragrance. Malini is also active in contributing to activities in the surrounding temples. With regard to providing opportunities for employees to carry out religious activities, Malini provided the widest possible opportunity. Malini also carried out efforts for the preservation and development of religious traditions, one of which was through praying every Purnama.

\section{Discussion}

The results of interviews and observations made by researchers indicate that the green economy is reflected in the business activities carried out by Malini Agro Park. The things that underlie this conclusion are looking at Malini's five flagship programs, namely:

1) Pecatu Farmers Empowerment Program

2) Organic Mustard Juice Drinking Movement Program

3) Malini Learning Farm Program

4) Malini Ambassador Program

5) Malini Agropark Tourism Program

The five flagship programs show that Malini is implementing a green economy, namely protecting and increasing the value of the natural resource base and increasing the efficiency of natural resources. In addition, these operations promote sustainable or environmentally friendly patterns of production and consumption, and push the world towards low-pollution development. The results of the interview also received a description of the application of the Triple Bottom Line Accounting and Tri Hita Karana aspects which are reflected in the company's activities, including in environmental, energy, occupational health and safety aspects, products, community involvement, and Parahyangan aspects.

However, in the application of green accounting, namely efforts to specify the financing made by companies in conducting environmental conservation into environmental posts in the company's business practices have not been fully carried out by the company (Malini). This is still an input for Malini to implement, because Malini itself will only be launched in January 2018. It is hoped that the 
development of green accounting or environmental accounting can be used as a tool for environmental management and as a means of communication between companies and the community. The application of environmental accounting is also expected to improve the efficiency of environmental management through an assessment of environmental activities from the point of view of environmental costs incurred with the benefits obtained by the company or the effects it causes.

\section{CONCLUSION}

The results confirm that it shows that a green economy is reflected in the business activities carried out by Malini Agro Park. The things that underlie this conclusion are looking at Malini's five flagship programs, namely: Pecatu Farmers Empowerment Program, Organic Mustard Juice Drinking Movement Program, Malini Learning Farm Program, Malini Ambassador Program, and Malini Agropark Tourism Program.

The five superior programs and the results of the interviews show that Malini applies a green economy and applies the Triple Bottom Line Accounting and Tri Hita Karana aspects in the company's activities, including environmental, energy, occupational health and safety, product, community involvement, and Parahyangan aspects. The application of green accounting or environmental accounting is still an input for Malini to apply, because Malini itself will only be launched in January 2018.

\section{ACKNOWLEDGMENT}

This research was carried out thanks to the support of various parties. On this occasion, the authors would like to thank Udayana University for the financial assistance provided, colleagues at the Faculty of Economics and Business who provided support and endorsement so that this activity could be carried out, as well as the respondents who contributed to this research.

\section{REFERENCES}

[1] Darwin, Ali., "Akuntabilitas, Kebutuhan, Pelaporan dan Pengungkapan CSR bagi Perusahaan di Indonesia", Economics Business \& Accounting Review, Edisi 3, September. Hal: 83-97. FE UI. 2006.

[2] Elkington, John., "Cannibals with Forks, The Triple Bottom Line of Twentieth Century Business", Capstone, Oxford, 1997.

[3] Dias, Ana Claudia; Margaruda Louro; Louis Arroja; Isabel Capela., "Evaluation of The environmental Performance of Printing and Writing Paper using Life Cycle Assesment", Management of Environmental. Vol. 15, No. 5, 2004.

[4] Lako, Andreas., "Green Economy: Menghijaukan Ekonomi, Bisnis, \& Akuntansi”, Jakarta: Erlangga, 2005. 